\title{
Immunological Relationships of Bacterial L-Asparaginases
}

\author{
By SHOSHANA BASCOMB* \\ Department of Biochemistry, Imperial College of Science and Technology, \\ London $\mathrm{SW}_{7} 2 \mathrm{AZ}$ \\ AND K. A. BETTELHEIM \\ Department of Medical Microbiology, St Bartholomew's Hospital, \\ London $E C \mathrm{I} A{ }_{7} B E$
}

(Received 4 June 1975)

SUMMARY

Rabbit antisera against L-asparaginase preparations from Escherichia coli, Erwinia carotovora, Citrobacter sp. and Chromobacterium violaceum showed on immunoelectrophoresis that only the enzymes from $E$. coli and Citrobacter are immunologically related. Purified preparations had to be used to determine the immunological cross-reactions. Immunoelectrophoresis at different $\mathrm{pH}$ values yielded the zero mobility points of the enzymes. The activity of the Er. carotovora preparation was enhanced up to fourfold by homologous antiserum but not by normal sera. Heterologous antisera also enhanced, but only at a higher concentration. Less enhancement was observed for the other enzymes with antisera as well as with bovine serum albumin. Inhibition was not observed.

\section{INTRODUCTION}

L-Asparaginases have been used extensively for the treatment of experimental and human tumours (Capizzi, Bertino \& Handschumacher, 1970). For most of these studies enzymes isolated from bacteria have been used, as L-asparaginases have been found in many species (Imada et al. 1973) and methods for large-scale purification developed (Wriston \& Yellin, 1973; Bascomb et al. 1975). Repeated injection of L-asparaginase caused hypersensitivity in 5 to $20 \%$ of patients (Cooney \& Handschumacher, 1970). To avoid this allergic reaction and other long-term immunological effects, L-asparaginases with similar antitumour activities but of different antigenic specificities are needed to allow continued treatment of a responding but allergic patient. Therefore, when seeking further sources of Lasparaginase it is of paramount importance to establish, as early as possible, the immunological cross-reactions of the new enzyme with L-asparaginases in current use. The feasibility of determining the immunological cross-reactions of crude enzyme preparations is of particular interest.

Enzyme activity may be influenced by other proteins, particularly specific antibody. With most enzymes, interaction with specific antibody inhibits enzyme activity, but enhancement has also been described (Cinader, 1967; Pollock, Fleming \& Petrie, 1967; Dyke, 1967). Lee \& Bridges (1968) reported that various non-immune animal and human sera enhanced the L-asparaginase activity of $E$. coli extracts, but L-asparaginase of guinea-pig serum was enhanced only by human and sheep sera. Ho \& Jones (1969) showed that the activity of a purified $E$. coli enzyme was increased by normal sera or by albumin. They concluded that

\footnotetext{
* Present address: Department of Bacteriology, St Mary's Hospital Medical School, London W2 I PG.
} 
the effect was non-specific and that bovine serum albumin enhanced the L-asparaginase activity by coating the surface of the reacting vessel, thus preventing denaturation of the enzyme by adsorption. However, MacLennan, Wade \& Hawkins (1971) showed that homologous antisera inhibited the $E$. coli and Erwinia carotovora enzymes specifically.

This paper describes the immunological relationship between purified L-asparaginases from five different bacterial species and the effects of antibody on the in vitro activity of these enzymes.

\section{METHODS}

Organisms. Bacterial strains from the culture collection of the Biochemical Department of Imperial College were used, and their identity is given in the text.

Enzyme preparations. Commercial preparations of $\mathrm{L}$-asparaginase from $E$. coli were obtained from Bayer-Leverkuse (Farbenfachen Bayer AG, Germany) and those from Er. carotovora from the Microbiological Research Establishment, Porton.

Purified L-asparaginase from Citrobacter $\mathrm{c} 6$ was obtained by the method described by Bascomb et al. (1975). A similar method was used for the preparation of enzymes from Chromobacterium violaceum AI 53 and Proteus vulgaris AI08.

Crude extracts of Citrobacter $\mathrm{c} 6$ were prepared as follows: The organisms were grown in a 601 fermenter (Bascomb et al. 1975), harvested by centrifuging (Sharples No. 6 tubular bowl centrifuge at a rate of $100 \mathrm{l} / \mathrm{h}$ at 4 to $5{ }^{\circ} \mathrm{C}$ ) and resuspending the pellet in potassium borate buffer $(50 \mathrm{mM}, \mathrm{pH} 8 \cdot 0)$. The chilled $\left(4\right.$ to $\left.5{ }^{\circ} \mathrm{C}\right)$ resuspended bacteria were ruptured by passing through an APV Manton-Gaulin sub-micron disperser model $\mathrm{K}_{3}$ operated at a gauge pressure of $5 \times 10^{7} \mathrm{~Pa}$ bar and at a rate of $250 \mathrm{l} / \mathrm{h}$. The ruptured bacteria were centrifuged for $15 \mathrm{~min}$ at $4^{\circ} \mathrm{C}$ at $38000 \mathrm{~g}$ in an MSE high speed centrifuge, and the supernatant, which contained the enzyme activity, stored at $-20^{\circ} \mathrm{C}$.

Assay of L-asparaginase activity and protein. Enzyme activity was measured by three different methods. Method I : an automated procedure, based on estimating the ammonia released from the substrate after 15 min incubation with the enzyme preparation (Bascomb et al. 1975). This was used for the quantitative determination of enzyme activity. A control channel measuring ammonia content of the enzyme preparation and a channel measuring its protein content were included in the system. Method 2: an automated procedure with reaction time of $\mathrm{I} \min$ (Bascomb et al. 1975). This was used for the in vitro assay of enzymeantibody mixtures. Method 3: qualitative estimation of enzyme activity on immunoelectrophoresis slides. After electrophoretic separation, a strip of Whatman No. I filter paper soaked in $33 \mathrm{~mm}$ L-asparagine in physiological saline was laid on the gel, and incubated in a moist chamber in a $37^{\circ} \mathrm{C}$ incubator for $10 \mathrm{~min}$. The filter paper strip was then dried at $50{ }^{\circ} \mathrm{C}$, dipped in a $2 \%(\mathrm{w} / \mathrm{v})$ ethanolic solution of ninhydrin and dried at $50^{\circ} \mathrm{C}$ for 10 to $15 \mathrm{~min}$. Enzyme activity was indicated by a blue coloration (aspartic acid), while the unchanged asparagine was brown. The size of the blue area was used for a rough estimation of enzyme activity.

Antibody production. New Zealand white rabbits ( 2 to $3 \mathrm{~kg}$ ) were used. Blood was obtained before injection and the serum found free of antibodies to any of the asparaginases tested. These 'pre-inoculation' sera were used as controls in some of the experiments. One week after bleeding, $0.5 \mathrm{ml}$ of enzyme preparations ( $10 \mathrm{mg}$ protein $/ \mathrm{ml}$ sterile saline) plus an equal volume of Freund's complete adjuvant were inoculated intramuscularly into one hind leg. Five weeks later $0.25 \mathrm{ml}$ of enzyme preparation (I $\mathrm{mg}$ protein $/ \mathrm{ml}$ ) was inoculated intramuscularly into each hind leg and $0 . \mathrm{I} \mathrm{ml}$ of the same preparation intravenously. The rabbits were bled I week afterwards. The blood was allowed to clot at room temperature, and the 

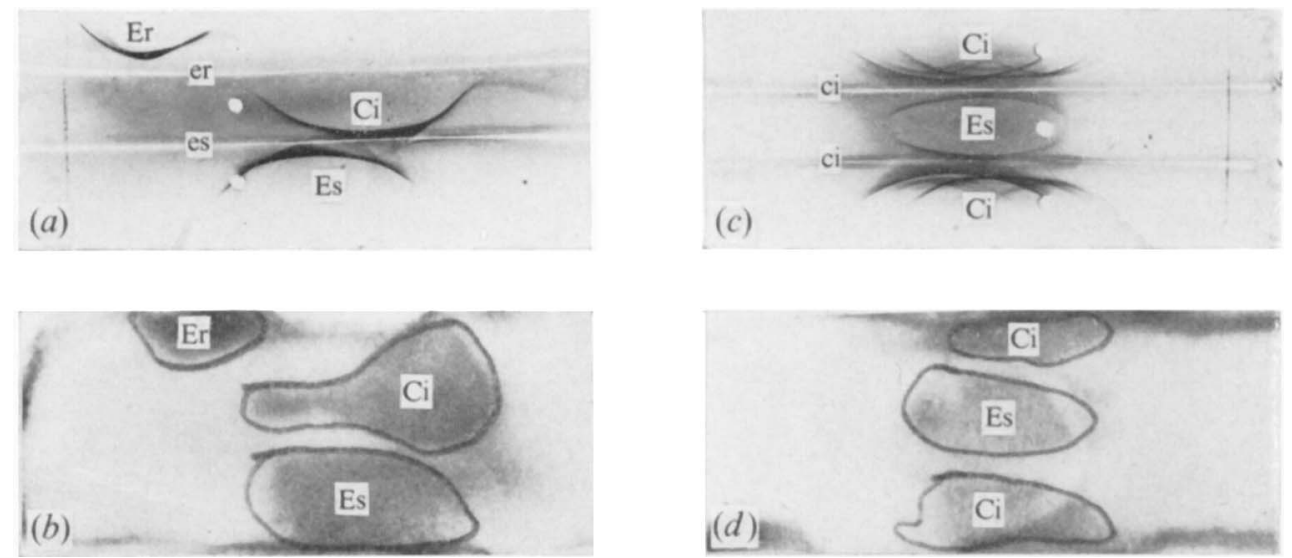

Fig. I. Cross-reactivity of bacterial L-asparaginases with antisera. Electrophoresis was in 20 mMpotassium phosphate buffer pH 8.0. (a) Immunoelectrophoresis of Er. carotovora (Er), Citrobacter sp. (Ci) and $E$. coli (Es) enzymes with rabbit antisera against Er. carotovora (er) and $E$. coli (es) enzymes. (b) L-Asparaginase activity of enzymes on slide (a) as detected by method 3. (c) Immunoelectrophoresis of Citrobacter sp. and $E$. coli enzymes with rabbit antisera (ci) against Citrobacter sp. enzyme preparations from two batches. $(d)$ L-Asparaginase activity of enzymes on slide $(c)$ as detected by method 3 .

serum was removed by pipette and centrifuged at $300 \mathrm{~g}$ for $30 \mathrm{~min}$ to remove the remaining red cells. All sera were stored at $-20^{\circ} \mathrm{C}$.

Electrophoresis. Potassium phosphate buffers $(20 \mathrm{~mm})$ of different $\mathrm{pH}$ values, as described by Bettelheim \& Taylor (1970), were used in all studies. Standard Shandon equipment was employed both for cutting antigen wells and antiserum troughs in the gels, which contained $\mathrm{I} \cdot 2 \%$ (w/v) Ion-Agar No. 2 (Oxoid), and for electrophoresis. A constant voltage of $200 \mathrm{~V}$ was maintained for $\mathrm{I} \mathrm{h}$, during which time the current increased from 30 to $60 \mathrm{~mA}$. After electrophoresis the position of the enzymes on the slide was located by method 3. Antisera were then placed in the troughs, and the slides incubated in a humid chamber at room temperature for $24 \mathrm{~h}$ before washing and staining (Bettelheim \& Taylor, 1970).

\section{RESULTS}

\section{Immunoelectrophoresis with homologous and heterologous sera}

Antisera prepared against enzyme preparations from Citrobacter c6, Chr. violaceum AI 53, $E r$. carotovora and $E$. coli were each tested against all four enzymes by immunoelectrophoresis at different $\mathrm{pH}$ values. A typical slide is shown in Fig. I(a). Erwinia carotovora and E. coli enzymes gave only one precipitin line with their homologous antisera. The position of this line always coincided with the position of asparaginase activity on the filter paper strip (Fig. I b). When Citrobacter and Chr. violaceum enzymes were tested against their homologous sera, a number of precipitin lines were observed (Fig. I c). Only one of these lines coincided with the position of enzyme activity on the filter paper. For immunological comparisons the position of the enzyme was determined as that precipitin line which was closest to enzyme activity. When the Citrobacter preparation was tested against $E$. coli antiserum, only one line was observed. Its position coincided at all $\mathrm{pH}$ values with the enzyme line detected with the Citrobacter antiserum. Conversely, when the $E$. coli enzyme was tested against the Citrobacter serum, only one line was observed in the same position as detected with the $E$. coli antiserum. An immunological relationship was detected only between the $E$. coli and Citrobacter enzymes. 


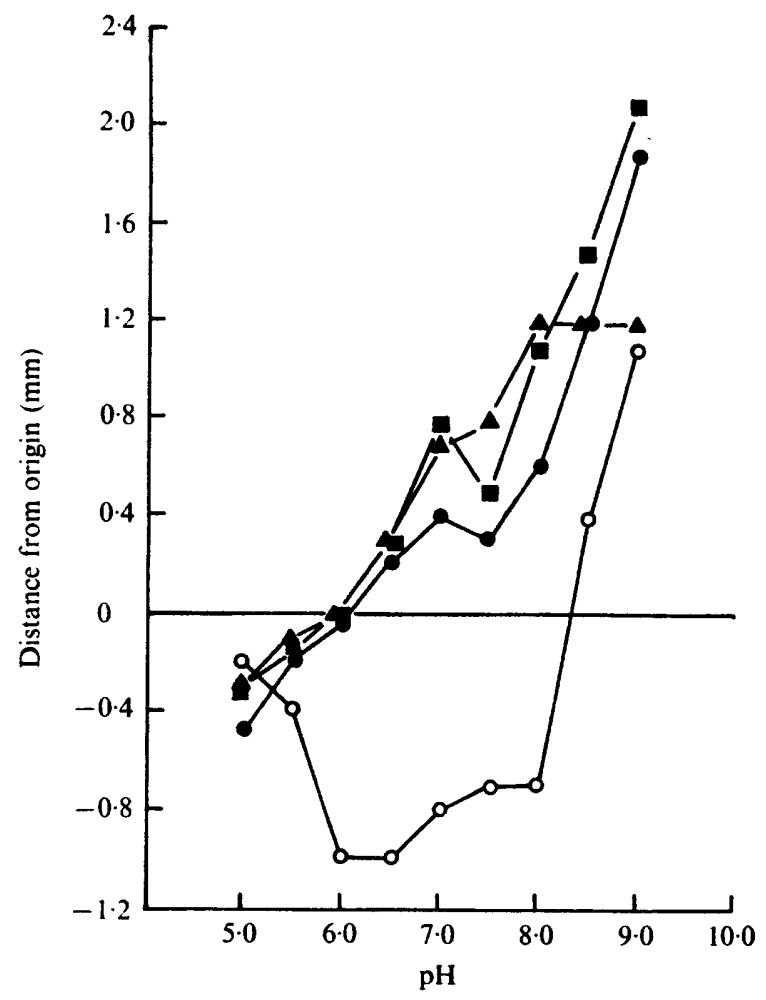

Fig. 2. Electrophoretic mobility of bacterial L-asparaginases. Electrophoresis was performed with $1 \cdot 2 \%(w / v)$ ion agar (Oxoid No. 2) in $20 \mathrm{~mm}$ potassium phosphate buffers. Source of enzymes:

$\mathbf{\square}$, Citrobacter sp.; $\mathbf{A}$, Chr. violaceum; О, E. coli; $\bigcirc$, Er. carotovora.

The possibility of detecting cross-reactivity in crude preparations from Citrobacter was investigated with antisera against the $E$. coli and Citrobacter enzymes. The ruptured bacteria and supernatant of Citrobacter were subjected to electrophoresis at $\mathrm{pH} 6.0$ and enzyme activity could be detected in both by method 3 . Although clear precipitin lines were observed when each antiserum reacted with its homologous antigen, the two crude Citrobacter preparations reacted only faintly with Citrobacter antiserum and barely visibly with the E. coli antiserum. Therefore, it would appear that crude extracts do not permit the detection of immunological relationships of L-asparaginases and purer enzyme preparations are necessary.

A parrially purified enzyme preparation from $P$. vulgaris AI08 was tested against all four antisera at $\mathrm{pH} 8 \cdot 0$. It formed a precipitin line only with the $E$. coli antiserum at a position which coincided with that of the enzyme activity.

\section{Effect of $p H$ on electrophoretic mobility of enzymes}

The electrophoretic mobilities of the four purified L-asparaginases were studied at $\mathrm{pH}$ values ranging from 5.0 to 9.0 at $0.5 \mathrm{pH}$ unit intervals (Fig. 2). Enzyme mobility was estimated by measuring the distance between the antigen well and the point on the precipitin line nearest to the antiserum trough (Fig. I $a$ ). Each enzyme was tested against its homologous antiserum at every $\mathrm{pH}$ on at least three separate slides on two separate occasions. 
Table I. Effect of added protein on activity of $\mathrm{L}$-asparaginase from different bacteria

Enzymes were mixed with protein in 50 mM-potassium borate buffer pH $8 \cdot 0(1: 9, v / v)$, incubated for $30 \mathrm{~min}$ at $30^{\circ} \mathrm{C}$ and assayed by method $\mathrm{r}$. Enzyme activity of control samples for Citrobacter, Er. carotovora and $E$. coli enzymes was $4,1 \cdot 5$ and 14 i.u. $/ \mathrm{ml}$, respectively.

$\overbrace{\text { Type }}^{\text {Protein added }}$

None (control)

Rabbit pre-inoculation serum

Citrobacter antiserum

Er. carotovora antiserum

E. coli antiserum

Bovine albumin fraction $\mathrm{V}$
L-Asparaginase activity (\% of control) Source of enzyme:

$\begin{array}{ccc}\text { Citrobacter } & \text { Er. carotovora } & \text { E. coli } \\ 100 & \text { I00 } & \text { I00 } \\ 139 & \text { NT } & \text { NT } \\ 126 & 152 & \text { I35 } \\ 143 & 420 & 130 \\ 93 & 173 & 130 \\ 149 & 146 & 136\end{array}$

NT, not tested.

\section{Table 2. Effect of concentration of antiserum and incubation period on activity} of Er. carotovora L-asparaginase

Enzyme $(\mathrm{I} \cdot 2 \mathrm{i} . \mathrm{u} . / \mathrm{ml})$ was mixed in $50 \mathrm{~mm}$-potassium borate buffer $\mathrm{pH} 8 \cdot 0$, incubated with slight agitation at $37^{\circ} \mathrm{C}$ for the stated period and assayed at $\mathrm{r} / 250$ dilution by method 2 .

\begin{tabular}{|c|c|c|c|}
\hline \multirow{2}{*}{$\begin{array}{l}\text { Concentration of antiserum } \\
\text { in incubated mixture } \\
(\mathrm{mg} \text { protein } / \mathrm{ml})\end{array}$} & \multicolumn{3}{|c|}{$\begin{array}{c}\text { L-asparaginase activity ( } \% \text { of } \\
\text { control) } \\
\text { Incubation time (h) }\end{array}$} \\
\hline & 0 & $\mathbf{I}$ & 2.5 \\
\hline 0 & 100 & 35 & 36 \\
\hline \multicolumn{4}{|l|}{ Er. carotovora antiserum } \\
\hline $\begin{array}{l}0.29 \\
0.58\end{array}$ & $\begin{array}{l}147 \\
266\end{array}$ & $\begin{array}{l}147 \\
269\end{array}$ & $\begin{array}{l}133 \\
260\end{array}$ \\
\hline $2 \cdot 90$ & ASR & ASR & ASR \\
\hline $5 \cdot 80$ & ASR & ASR & ASR \\
\hline \multicolumn{4}{|l|}{ Chr. violaceum antiserum } \\
\hline 0.0 & 44 & 40 & 44 \\
\hline 0.3 & 44 & 66 & 48 \\
\hline 0.6 & 56 & 57 & 53 \\
\hline 3.0 & 188 & 236 & 214 \\
\hline $6 \cdot 0$ & ASR & ASR & ASR \\
\hline
\end{tabular}

ASR, Above sensitivity range of instrument.

\section{Effects of antibody on enzyme activity}

Enzymes of Citrobacter, E. coli and Er. carotovora were diluted in $0.9 \mathrm{ml}$ potassium borate buffer $(50 \mathrm{mM}, \mathrm{pH} 8.0)$ with $0.1 \mathrm{ml}$ of the various sera or albumin, incubated with gentle agitation for $30 \mathrm{~min}$ at $30^{\circ} \mathrm{C}$, and assayed for enzyme activity by method I. Enzyme activity was detected in all enzyme preparations but not in any of the added proteins. Free ammonia was not detected in any of the sera or the albumin. All three enzymes (Table 1 ) showed some increase in activity with added protein; activity of the Er. carotovora enzyme in homologous antiserum increased more than fourfold.

A more detailed study of the effect on activity of different concentrations of enzyme and antibody, and of the duration of incubation with antiserum, was investigated with the 
Er. carotovora enzyme by the more sensitive method 2 . The enzyme was diluted as before with $0.005,0.01,0.05$ and $0.1 \mathrm{ml}$ of its homologous serum (equivalent to $0.3,0.6,2.9$ and $5.8 \mathrm{mg}$ protein $/ \mathrm{ml}$, respectively), and the mixture assayed immediately and after I and $2.5 \mathrm{~h}$ gentle agitation at $37{ }^{\circ} \mathrm{C}$. The activity of enzyme agitated without serum was reduced within I h of of incubation (Table 2). Addition of homologous antiserum increased enzyme activity

1zero time even at the lowest dilution used $(0.3 \mathrm{mg}$ protein $/ \mathrm{ml}$ agitated mixture, or a final dilution in the assay mixture of $0.00 \mathrm{I} \mathrm{mg}$ protein $/ \mathrm{ml}$ ) and protected the enzyme from deterioration during incubation at $37^{\circ} \mathrm{C}$. The deterioration in activity of enzyme dilutions without added protein was detected in further experiments even at room temperature within 10 min of the dilution of the enzyme. Addition of heterologous antisera (Table 2) increased enzyme activity, but this increase was smaller and apparent only when $0.05 \mathrm{ml}$ of serum $(3.0 \mathrm{mg}$ protein $/ \mathrm{ml})$ was added. At such concentration of antiserum, enzyme activity did not deteriorate during $2.5 \mathrm{~h}$ incubation at $37^{\circ} \mathrm{C}$. Effects of antisera on activity of Citrobacter and $E$. coli enzymes were generally much less and rather variable.

\section{DISCUSSION}

The immunoelectrophoresis studies confirmed that the Er. carotovora and $E$. coli enzymes are serologically unrelated (MacLennan et al. 197I), and showed that the L-asparaginase from Chr. violaceum is again different. The Citrobacter enzyme is related to that from E. coli, as shown by the precipitin lines developed by each enzyme against the other antiserum. Nevertheless, the mobilities and zero mobility points (see below) of these two enzymes are slightly different, suggesting some structural differences. This is also shown by the molecular weights of these two enzymes, I 20000 to 127000 daltons for the $E$. coli enzyme (as quoted by Wriston \& Yellin, 1973) and 166000 daltons for that from Citrobacter (Bascomb et al. 1975). Escherichia and Citrobacter are closely related genera (Edwards \& Ewing, 1972) within the Enterobacteriaceae, while Erwinia, although in the same family, is less closely related to these two. Chromobacterium is not in the Enterobacteriaceae. A precipitin line was also observed with the $E$. coli serum and the $P$. vulgaris preparation. This serological relatedness was less expected, as Proteus and Escherichia belong to two different tribes of Enterobacteriaceae. These results are similar to those of Cocks \& Wilson (1972), who studied serological relationships between alkaline phosphatases from different bacterial taxa and concluded that the immunological relationships they observed corresponded with the accepted taxonomy of the groups.

By comparing the mobilities of the enzymes on the slides after electrophoresis at different $\mathrm{pH}$ values, a zero mobility point can be established for each enzyme at any set of specified conditions for electrophoresis. Theoretically, this point is related to the isoelectric point of the enzyme but is affected by the electroendosmosis specific to the electrophoretic conditions used. In comparison with the established methods of isoelectric focusing this method is much cheaper to perform and can be combined with serological and enzyme activity studies. It is, therefore, relevant to compare the isoelectric points found by isoelectric focusing (Robinson, 1972) with the zero mobility points found by our method. The Er. carotovora values of isoelectric focusing varied from $7 \cdot 7$ to 8.35 and those for the $E$. coli (Bayer) preparation varied from 4.95 to 5.5 . The points of zero mobility were 8.2 and 6.2 respectively (Fig. 2). The agreement in Erwinia is encouraging, while the discrepancy in the E. coli enyzme may be due to batch differences or the nature of the buffer used, or to electroendosmosis effects, as our method employed the rather highly charged agar for the gel matrix.

The non-specific enhancement of activity of the $E$. coli and Citrobacter enzymes confirms 
the results of Ho \& Jones (1969). MacLennan et al. (1971) showed that concentrations of homologous antiserum as low as I/25000 partially inhibited the $E$. coli and Er. carotovora enzymes and that increasing the concentration of antiserum to $I / 8$ increased the inhibition. However, our results do not confirm this finding. With the $E$. coli enzyme (Table I), homologous and heterologous sera had similar effects of increasing the enzyme activity by 30 to $36 \%$. With the Er. carotovora enzyme, homologous antiserum at concentrations ranging from $\mathrm{I} / 200$ to $\mathrm{I} / \mathrm{IO}$ caused an increase in enzyme activity (up to fourfold at $\mathrm{I} / \mathrm{10}$ ). Neither albumin at $0.1 \mathrm{mg} / \mathrm{ml}$ provided such a stimulation, nor did the non-immune or heterologous sera, although the latter gave some enhancement of activity at higher concentrations.

The enhancement of L-asparaginase activity by specific antibody which we found in vitro, may also occur in vivo. In such situations the determination of the clearance rate of the enzyme from the bloodstream as currently performed on serum might give misleadingly low results. If specific antibodies cause the attachment of enzyme to lymphocytes or other cells of the blood, most of the enzyme may not only remain undetected in the precipitated clot but also be enhanced.

The differences between our findings and those of MacLennan et al. (1971) may be explained on the basis of variation in the type of antibody response induced in individual rabbits. Cinader (1967) reported that five out of six rabbits produced inhibitory antibodies to ribonuclease, while the sixth consistently produced an antibody which increased the activity of the enzyme. Such variation in type of antibody response may contribute to the variability of patient response to $L$-asparaginase treatment.

We thank Professor Sir Ernst Chain for interest and support and Mr C. A. Grantham, Mr A. Kamalgharan and Miss Janny Shearer for skilled technical assistance. The work was supported by the Cancer Research Campaign.

\section{REFERENCES}

Bascomb, S., Banks, G. T., Skarstedt, M. T., Fleming, A., Bettelheim, K. A. \& Connors, T. A. (1975). The properties and large scale production of L-asparaginase from Citrobacter. Journal of General Microbiology 91, 1-I6.

Bettelheim, K. A. \& TAYlor, J. (1970). Soluble antigens of enteropathogenic Escherichia coli. Journal of Medical Microbiology 3, 655-667.

Capizzi, R. L., Bertino, J. R. \& Handschumacher, R. E. (1970). L-Asparaginase. Annual Review of Medicine 21, 433-444.

CinADER, B. (1967). Antibodies to enzymes - a discussion of the mechanisms of inhibition and activation. In Antibodies to Biologically Active Molecules. Proceedings of the 2nd Meeting of the Federation of European Biochemical Societies, Vienna 1965, vol. I, pp. 85-137. Edited by B. Cinader. London: Pergamon Press.

Cocks, G. T. \& WILson, A. C. (1972). Enzyme evolution in the Enterobacteriaceae. Journal of Bacteriology I10, 793-802.

COONEY, D. A. \& HANDSChumaCHER, R. E. (1970). L-Asparaginase and L-asparagine metabolism. Annual Review of Pharmacology 10, $42 \mathrm{I}-440$.

DYKE, K. G. H. (1967). Surface-specific inactivation of staphylococcal penicillinase. Biochemical Journal 103, $641-646$.

EDWARDS, P. R. \& EWING, W. H. (1972). Identification of Enterobacteriaceae, 3rd edn. Minneapolis: Burgess.

Ho, P. P. K. \& JonEs, L. (I969). The effect of animal sera and bovine serum albumin on L-asparaginase determination in vitro. Biochimica et biophysica acta 177, 172-174.

Imada, A., I garasi, S., NAKAhAMA, K. \& Isono, M. (1973). Asparaginase and glutaminase activities of microorganisms. Journal of General Microbiology 76, 85-99.

LEE, M. B. \& BRIDGES, J. M. (1968). L-Asparaginase activity in human and animal sera. Nature, London 217 758-759. 
Maclennan, A. P., Wade, H. E. \& Hawkins, D. C. (1971). The immunological specificity of bacterial L-asparaginases. In Colloques Internationaux C.N.R.S. No. 197, La L-asparaginase, pp. 409-424. Paris: Centre nationale de la recherche scientifique.

Pollock, M. R., Fleming, J. \& Petrie, S. (1967). The effects of specific antibodies on the biological activities of wild-type bacterial penicillinases and their mutationally altered analogues. In Antibodies to Biologically Active Molecules. Proceedings of the 2nd Meeting of the Federation of European Biochemical Societies, Vienna 1965, vol. I, pp. 139-152. Edited by B. Cinader. London: Pergamon Press.

RoBinson, H. K. (1972). Comparison of different techniques for isoelectric focusing on polyacrylamide gel slabs using bacterial asparaginases. Analytical Biochemistry 49, 353-366.

Wriston, J. C., JUN. \& YelLIN, T. O. (1973). L-Asparaginase: a review. In Advances in Enzymology, vol. 39, pp. 185-248. Edited by A. Meister. New York: John Wiley \& Sons. 